\title{
Some Conceptual Issues in the Modeling and Computational Analysis of the Canada-U.S. Free Trade Agreement
}

\author{
DRUSILLA K. BROWN and ROBERT M. STERN
}

\begin{abstract}
We present an interpretive history of the development of the computational analysis of the Canada-U.S. FTA. Several important conceptual issues are identified, including: perfect competition and national product differentiation; imperfect competition and increasing returns to scale; tariff liberalization and monopolistic competition; adjustment and dynamic effects; macroeconomic effects; and other pertinent aspects of market structure and firm behavior.
\end{abstract}

\section{INTRODUCTION}

In the last decade numerous studies of the economic effects of the Canada-U.S. Free Trade Agreement (FTA) have been undertaken. While these studies apparently played an important role in the public debate over the FTA, it is especially noteworthy that the research results reflect a wide array of conflicting conclusions. Thus, it is difficult to answer some basic questions about the FTA, such as whether it will be welfare improving for Canada and/or the United States, whether the labor productivity gap between the two nations will be narrowed, whether capital will be repatriated out of Canada, whether labor markets will be severely dislocated, or whether Canadian and/or U.S. firms will realize economies of scale. Nevertheless, research on the FTA has advanced our understanding of the links among market structure, trade liberalization and the realization of scale economies, and the theoretical and empirical modeling of preferential trading arrangements.

Now that the FTA has become operative, this seems like an appropriate time to assess what we have learned and to ask what aspects of our models are in need of further clarification. The purpose of our paper, accordingly, is to review some important conceptual issues that are pertinent to the analysis of the economic effects of the Canadian-U.S. FTA. ${ }^{1}$ This should in turn help in designing future research that will analyze the actual effects of the FTA in the coming decade as well as the effects of the North American Free

Drusilla K. Brown - Department of Economics, Braker Hall, Tufts University, Medford, MA 02155. Robert M. Stern - Institute of Public Policy Studies, University of Michigan, Ann Arbor, MI 48109-1220.

North American Journal of Economics \& Finance, 3(1):1-20 
Trade Area involving Canada, the United States, and Mexico that is currently being negotiated.

The organization of our paper is as follows. In Sections II to VII, we present an interpretive history of the development of the computational analysis of the FTA. In the course of this discussion, we identify several important conceptual issues, including: perfect competition and national product differentiation; imperfect competition and increasing returns to scale; tariff liberalization and monopolistic competition; adjustment and dynamic effects; macroeconomic effects; and certain other important aspects of market structure and firm behavior. Some conclusions and implications for further research are discussed in Section VIII.

\section{PERFECT COMPETITION AND NATIONAL PRODUCT DIFFERENTIATION (NPD)}

One of the earliest computable general equilibrium (CGE) studies of Canadian tariff elimination was undertaken by Boadway and Treddenick (1978), who constructed a multisector model of Canada, with trade incorporated through net rest-of-world import-demand and export-supply functions. Their structure was based closely on the standard neoclassical model of international trade, with the exception that goods were assumed to be nationally differentiated. That is, imports and the domestic variety of each good were imperfect substitutes from the point of view of consumers and producers.

The assumption of national product differentiation (NPD) was first adopted in the CGE models of the mid-to-late 1970s and has been a prominent feature of CGE work throughout the 1980s. NPD was originally introduced as a means of reducing the domestic market's response to fluctuations in world prices. NPD was also useful in eliminating the possibility that trade liberalization would leave a country completely specialized in a subset of product aggregates.

In the type of model used by Boadway and Treddenick, the effects of tariff elimination are governed principally by the choice of the rest-of-world's import-demand elasticity. Thus, the higher the foreign import-demand elasticity, the greater the welfare gain to Canada from unilateral tariff elimination. This result follows from the fact that, for high values of the foreign demand elasticity, Canada has little implicit market power. The efficiency gains associated with liberalization therefore dominate the welfare-reducing effect of a deterioration in the terms of trade.

The work of Boadway and Treddenick was extended to a multi-country setting by Hamilton and Whalley (1985), who employed the same demand and supply structure in an eight-region computational model, but with the important exception that the final demand and input-output structures of each of the eight country groups were modeled explicitly. The NPD framework proved to be especially useful in the multi-country setting since preferential trading arrangements such as the Canada-U.S. FTA require that the modeler be able to identify the imports that are to receive preferential treatment. This is an extremely difficult problem if products are homogeneous. But with NPD, bilateral trade flows are each modeled individually so that trade flowing through preferential channels is easily identified.

As noted in Table 1, Hamilton and Whalley found that a Canada-U.S. FTA would reduce U.S. welfare by 0.04 percent and increase Canadian welfare by 0.6 percent. This 
TABLE 1. Summary of Studies of Estimated Changes in Real Income Resulting from a U.S.-Canadian Free Trade Agreement

\begin{tabular}{cccc} 
& \multicolumn{3}{c}{ Change in Real Income } \\
\cline { 2 - 4 } & & United & Other \\
Study & Canada & States & Countries \\
\hline
\end{tabular}

Gencral cquilibrium models

A. Perfect competition and constant returns to scale

Hamilton and Whalley (1985)

Brown and Stern (1987)

0.6

$-0.3$

$-0.04$

0.03

Negative

B. Imperfect competition and increasing

returns to scale

Harris and Cox (1985)

Canadian Department of Finance (1988)

Markusen and Wigle (1986)

Wigle (1988)

Brown and Stern (1989a)

Macroeconometric models

Informetrica (1985)

Institute for Policy Analysis (1985)

Wharton Econometrics (1987)

Economic Council of Canada

(1987)

(1988)

$\begin{array}{rrr}8.9 & & \\ 2.5 & 0.1 & \text { Negative } \\ 0.6 & 0.1 & \\ -0.1 & 0.1 & -142.7 \\ 1.1 & & \end{array}$

3.0

3.3

3.1

3.3

2.5

Notes: The estimates reported are sensitive to the degree of response of exports and imports to changes in relative prices. The results in the Harris and Cox and Department of Finance analyses are sensitive to the price response of import-competing manufacturing firms to the reduction of domestic trade barriers. Estimates for a given study vary due to different assumptions about the extent of trade liberalization and the size of the rationalization gain resulting from freer trade. The complete citations for the studies noted are given in the list of references.

Source: Adapted in part from Government of Canada, Department of Finance (1988, p. 32).

result is somewhat surprising given that Canada's pre-FTA tariffs are somewhat higher than U.S. tariffs. Rather, it might have been expected, with constant returns to scale and NPD, that removal of Canada's relatively higher tariffs would worsen Canada's terms of trade and reduce its welfare.

It seems that Hamilton and Whalley's specification of the elasticity of substitution between imports and the domestically produced good lies behind their anomalous result. They set the elasticity of substitution equal to 1.66 for the United States and 1.02 for Canada. Consequently, U.S. consumers are assumed to be considerably more sensitive than Canadian consumers to changes in import prices. A U.S. tariff reduction will thus have a much stronger impact on the demand for Canadian produced goods than an equal reduction in the Canadian tariff would have on the demand for U.S. produced goods. In order to eliminate the relative excess demand for Canadian produced goods, Canadian terms of trade must improve.

Brown and Stern (1987) used a model that was very similar to Hamilton and Whalley, but they imposed the restriction that the elasticity of substitution between imports and the domestic good be comparable across countries. As noted in Table 1, their results sug- 
gested that bilateral tariff removal would raise U.S. welfare by 0.03 percent and lower Canadian welfare by 0.3 percent, based on trade in 1976 .

The results of the Hamilton-Whalley and Brown-Stern models are useful in illustrating the importance of the NPD assumption. In particular, Brown (1987) has shown that this seemingly innocuous assumption has the property that changes in the terms of trade dominate the welfare conclusions. The efficiency effects of liberalization normally emphasized by trade economists have only a secondary role at best in these circumstances.

It is surprising in retrospect that the terms-of-trade issue would even arise given Canda's small size relative to the rest of world and the presumption that Canada exercises little influence on world prices. However, NPD implies that each country can exercise a kind of nationally differentiated, oligopolistic market power over the supply of its own variety of each good. Consequently, each country is taken to be large in the sense that the demand for its exports is less than perfectly elastic. ${ }^{2}$ At the same time, gains from specialization are minimized because production cannot be relocated to the country with the lowest cost of production. Moreover, this property of NPD models cannot be alleviated by raising the elasticity of substitution among different national varieties of a good.

Given the nature of the NPD assumption and its welfare implications, other procedures for identifying bilateral trade flows appear worth exploring. Interestingly, introducing imperfect competition provides a solution to this problem. One alternative, such as 'focal pricing,' as in Harris (1984), generally predicts a welfare gain for Canada despite a deterioration in the terms of trade.

A monopolistically competitive market structure provides a second alternative. That is, rather than assuming NPD, firms themselves can be modeled as selling differentiated products, as in Brown and Stern $(1989 \mathrm{a}, \mathrm{b})$. National market power is thereby eliminated because firms can move from one national location to another. In addition, the market power that exists as a result of product differentiation is already exercised by the firm when its sets a profit-maximizing mark-up of price over marginal cost, leaving little additional role for government intervention.

A third alternative is to differentiate consumers, as in Venables (1985) and Brown and Stern $(1989 a, b)$. Firms frequently seek to segment markets with differing demand elasticities in order to engage in price discrimination. If it is assumed that arbitrage between national markets is inhibited, then a firm will set a profit-maximizing price and quantity for each national market. Thus, export supplies are differentiated by destination.

A fourth approach is to model goods as homogeneous across countries, thus allowing for the possibility of complete specialization. In addition, preferential trading of homogeneous products will eliminate some bilateral trade flows, particularly between the smaller of the two partners and the rest of the world. Though computationally difficult, this modeling strategy has been employed by Trela and Whalley (1990) in the context of the Multi-Fibre Agreement.

\section{IMPERFECT COMPETITION AND INCREASING RETURNS TO SCALE}

Models with perfect competition and NPD have also been criticized for ignoring the potential gain from increasing competition among imperfectly competitive firms, particularly in Canada. Many influential Canadian scholars have long argued that Canada's 
import restrictions may have resulted in suboptimal manufacturing plant size, short production runs, and excessive product diversity. Further, U.S. import restrictions may have reinforced the foregoing characteristics of Canadian manufacturing by limiting the access of Canadian firms to the U.S. market.

Particularly noteworthy here is the pioneering effort of Wonnacott and Wonnacott (1967) who sought to analyze and measure the potential gains from free trade between Canada and the United States as the result of the realization of scale economies and the increased product variety that mutual market access would make possible. According to this line of reasoning, with the removal of bilateral tariffs and NTBs, Canadian firms would be induced by increased competitive pressures and profit considerations to take advantage of enhanced market opportunities by expanding output and reducing the number of product varieties. In view of the potential significance of rationalization effects, reallocation of capital and labor would be expected to be largely intra-industry in character rather than inter-sectoral.

While there may well be rationalization as the result of a Canada-U.S. FTA, questions arise about the actual importance of rationalization and the economic factors that will govern its realization. The relatively low bilateral tariff rates suggest that U.S. and Canadian firms already enjoy substantial access to each other's markets. Furthermore, Canadian firms have had to adapt to the multilateral tariff reductions implemented during the 1970s and 1980s as the result of the Kennedy and Tokyo Round negotiations. How large the benefits from rationalization will be as the result of the FTA is therefore unclear.

In this context, Harris (1984) and Harris and Cox (1984, 1985) constructed a highly innovative computational model in which firms in many manufacturing industries face declining average cost. That is, firms must invest a fixed amount of capital and labor before a production run can begin so that average total cost (ATC) is declining for all firms. They also extended the standard model to allow for the possibility that each firm might sell a differentiated product.

The firms in the Harris-Cox model may follow two pricing strategies. Monopolistically competitive firms calculate (or estimate) the elasticity of demand for their product and then set the price-cost margin to maximize profits. Tariff liberalization is assumed to raise the firm's perceived elasticity of demand by enhancing the market power of U.S. firms selling in the Canadian market. The profit-maximizing price-cost margin thus falls and firm output rises.

In addition, firms may tacitly collude, focusing on a single easily observable price. This pricing behavior, due originally to Eastman and Stykolt (1967), posits that each firm charges the landed price of imports. However, freedom of entry guarantees that this focal price is also equal to ATC. Liberalization exercises a very strong influence on the focal price and firm output in this setting. Tariff removal lowers the landed price of imports leaving firms earning negative profits at the pre-agreement level of output. In order to restore the zero-profits condition, firms that do not exit must raise output and move down the ATC curve. Under the focal pricing assumption, therefore, liberalization will have a powerful impact on Canadian productivity and welfare.

Harris and Cox conducted both unilateral and multilateral free trade experiments for Canada and the rest of world. Their results suggest that the welfare gains for Canada would be positive for both experiments and much larger than those obtained by the kinds of models based on perfect competition and constant costs that were described in the preceding section. As noted in Table 1, the gains from multilateral liberalization were 
estimated to be as much as 8.9 percent of Canada's gross national expenditure. It is interesting that this estimate is comparable to the 10.5 percent welfare gain calculated by the Wonnacotts based on tariff rates and other economic data and assumptions pertaining to the 1960 s.

Subsequently, the Canadian Department of Finance (1988) used the Harris-Cox model with more recent and corrected data and obtained an estimated welfare gain of 2.5 percent, which is considerably less than the original Harris-Cox result. Nonetheless, since the same model was being used, it is the case that rationalization effects remain the driving force, resulting from the mixed pricing behavior being assumed for the imperfectly competitive Canadian manufacturing firms.

The large projected welfare gains in the Harris-Cox model may have generated considerable enthusiasm for the FTA in Canada. However, work by Wigle (1988) qualified the Harris-Cox results in several important ways. Wigle extended the Hamilton-Whalley eight-region model described above to incorporate the industrial organization characteristics developed by Harris and Cox. But unlike Harris and Cox, Wigle fully modeled the internal economies of countries other than Canada. In addition, rather than employing both the monopolistic competition pricing strategy and the collusive focal pricing strategy in all industries, he assumed each industry to be either monopolistically competitive, collusive, or perfectly competitive.

As noted in Table 1, Wigle estimated that bilateral 1976 tariff elimination would increase U.S. welfare by 0.1 percent and that Canada's welfare would decline by 0.1 percent, based on trade in 1977. In both of the imperfectly competitive industries, firm output rose and ATC declined. However, Canada's terms of trade deteriorated by 2.6 percent and the U.S. terms of trade improved by 0.6 percent. Thus, as in the perfectly competitive multi-country general equilibrium models, Wigle's results suggest that changes in the terms of trade dominate efficiency and rationalization effects in determining the change in welfare.

Though the Harris-Cox and Wigle models are broadly similar in structure, their opposing welfare conclusions are nevertheless instructive. Harris and Cox emphasize collusive firm behavior that is facilitated by trade barriers that insulate domestic firms from foreign competition. As a result, trade liberalization has a very strong effect that forces firms to cut price and increase output. In contrast, Wigle places relatively more emphasis on the monopolistically competitive market structure, in which trade barriers play a much less important role in facilitating collusion. Thus, the pro-competitive gains from liberalization are smaller. It is nevertheless disturbing that Wigle finds Canadian welfare declining. As discussed above, the supposition was that the multi-country models would predict mutual gains from bilateral liberalization if bilateral trade flows were identified using firm product differentiation rather than national product differentiation.

\section{TARIFF LIBERALIZATION AND MONOPOLISTIC COMPETITION}

The preceding discussion, comparing the results of Harris and Cox and Wigle, suggests that it might be useful to examine the monopolistically competitive market structure in its own right. In this context, there are three potential sources of welfare gain from trade liberalization for Canada: inter-sectoral specialization; rationalization; and changes in the terms of trade. Each is discussed in turn. We then reconsider the Wigle results in light or our theoretical discussion of tariff liberalization and monopolistic competition. 


\section{Inter-Sectoral Specialization}

In constructing his computational model of Canada-U.S. tariff liberalization, Wigle assumed that product differentiation exists at both the firm and the national level. This is the case, even though NPD is not necessary to maintain three-way trade in the presence of firm product differentiation. Given the unnecessary and ad hoc nature of the NPD specification, it is worth pointing out the implications of this assumption for the computations. In particular, NPD focuses the model on intra-industry trade and minimizes the necessary inter-sectoral factor movements. Therefore, NPD models tend to predict comparatively little labor-market disruption due to liberalization, whereas they understate welfare gains associated with realizing comparative advantage based on inter-sectoral factor reallocation.

In the context of a perfectly competitive market structure with NPD, the tendency toward increased intra-industry trade is fairly obvious. NPD implies that production of each variety of a good cannot be transferred from one national location to another. The potential for specialization in production is thus severely inhibited.

To see this point in an imperfectly competitive setting, consider a simple model in which firms within one country produce identical goods, but imports and domestically produced goods are differentiated. Assume that consumers first allocate expenditure between the import aggregate and the domestic good and then allocate expenditure on each aggregate among individual firms. This implies that demand for imports from a foreign firm does not depend on the number of individual domestic firms. Rather, demand for an imported variety depends only on the level of the domestic aggregate consumed. This framework differs importantly from the pure monopolistically competitive model in which consumers are not interested in whether a product is produced domestically or imported. In that case, all products enter symmetrically in the utility function.

The implications of NPD in the monopolistically competitive case can be seen by considering the adjustment process in response to a tariff, as shown in Figure 1. Here preliberalization equilibrium is illustrated for a representative domestic firm where the firm's demand curve, $d$, is tangent to its ATC curve. Removing the import tariff will reduce demand for the domestic variety so that a representative firm's demand curve shifts to $d^{\prime}$ and each domestic firm earns negative profits. The opposite is the case for a representative foreign firm that is enjoying increased demand for its product.

In the transition to the long run in which profits return to zero, the number of domestic firms falls as firms losing money exit, and the number of foreign firms increases. It is obviously the case that the smaller number of domestic firms will increase the demand for an individual domestic firm remaining in the market. However, will the rise in the number of foreign firms lower the demand for a typical domestic firm? In the context of the monopolistically competitive model with NPD, the answer is clearly negative. Whether there are ten foreign firms each selling 100 units of the foreign variety or 100 foreign firms each selling ten units is immaterial to the demand for the domestic good or the demand for individual domestic firms. Consequently, the exit of domestic firms shifts the demand for individual domestic firms from $d^{\prime}$ to $d$, restoring the zero-profits condition.

The essential equilibrating mechanism here is that the number of local firms rises or falls, spreading a given level of production over a larger or smaller number of firms until profits once again return to zero. The only factor movement necessary to restore equilibrium is the fixed input requirement. The fewer the number of domestic firms, the more fixed capital that is released to other sectors of the economy. 


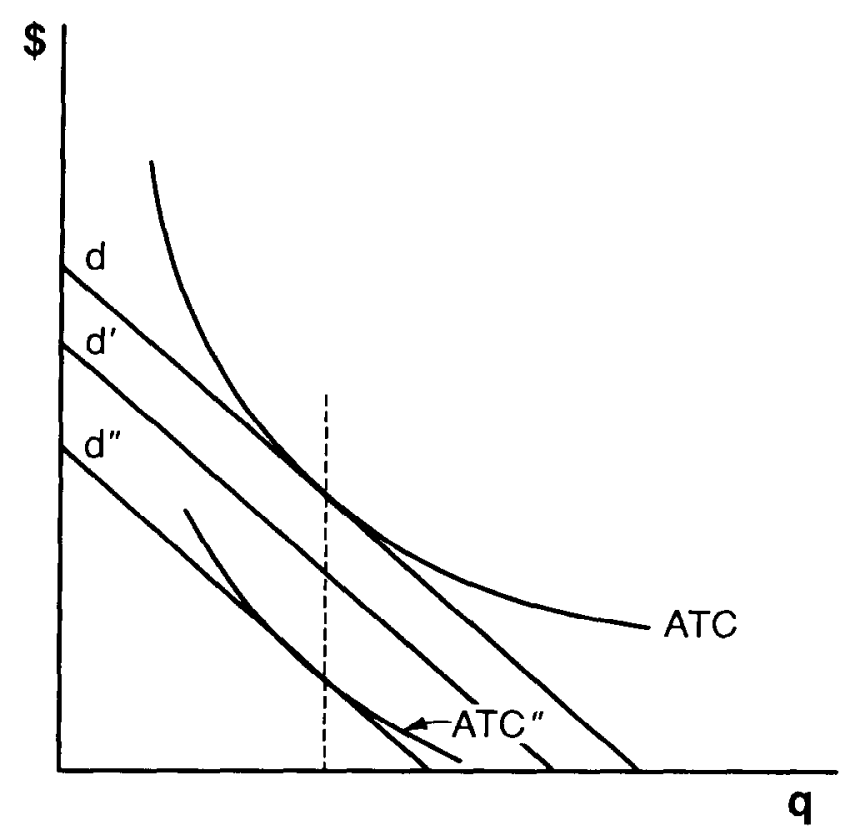

Figure l

We now consider the adjustment process in the absence of NPD. In this case, consumers determine demand for output of all firms in a single stage. Therefore, the movement in a domestic firm's demand curve depends on whether there is global entry or exit, not whether there is local entry or exit. If on balance the increase in the number of foreign firms exceeds the fall in the number of domestic firms, the demand for a representative domestic firm continues to fall below $d^{\prime}$ to a position such as $d^{\prime \prime}$.

How can the zero-profits condition be restored in this case? As domestic firms exit, the relative cost of the factor used intensively in the production of the good under consideration must fall. As a result, marginal cost (MC) also begins to fall and the firm's ATC curve begins to shift down. Exit will occur until the firm's ATC has shifted to ATC", which is tangent to the firm's new demand curve, $d^{\prime \prime}$. Therefore, the adjustment process in this case depends entirely on inter-sectoral factor mobility which lowers ATC. We would expect then that considerably more inter-sectoral factor movements will emerge from Canada-U.S. tariff elimination in models that do not impose NPD. Short-run labor market dislocation could be severe, but compensating long run gains from specialization could be substantial.

\section{Rationalization}

We now consider the effects of trade liberalization on firm output under monopolistic competition. In the monopolistically competitive market structure, firm output is determined where the firm's ATC is tangent to its demand curve $\left(d_{0}\right)$, as shown in Figure 2. Either an increase in the elasticity of the firm's demand curve or a steepening of the ATC curve will cause the point of tangency to occur at a level of output above $q_{0}$. Our intuition 
concerning the effect of trade liberalization on firm output and economies of scale is based on an analysis of the impact of a tariff on firm perceived elasticity of demand. Thus, we turn first to isolate the influence of a tariff on the shape of the demand curve.

It is convenient at this point to choose a specific functional form, though the results below apply to a large class of utility functions. Suppose that consumer preferences over all varieties of a good are defined by a CES function. It is straightforward to demonstrate (see Lancaster 1984) that a representative firm's perceived elasticity of demand is increasing in its own price, decreasing in the price of other varieties, and increasing in the number of competing firms. In other words, as the firm moves up its demand curve, demand becomes more elastic. On the other hand, a rise in the price of a competing variety causes a rightward shift in the firm's demand curve and a fall in elasticity. Similarly, the more competitors a firm has, the more elastic is an individual firm's demand curve.

Consider now a reduction in the foreign tariff. Great emphasis has been placed on the importance of access to U.S. markets as a means of allowing Canadian firms to increase output and thereby reap rationalization gains. However, as shown by Horstmann and Markusen (1986) in the case of a monopolisitically competitive market structure, a fall in the foreign tariff actually tends to reduce individual firm output. To see this, note that a change in the foreign tariff does not affect the firm's demand in the domestic market but will lower its price relative to foreign firms in the export market. Thus, export demand becomes less elastic.

Our point is illustrated in Figure 2. In the initial tariff equilibrium, the firm's ATC is tangent to the tariff distorted export demand, given by $d_{0}$, and firm output is $q_{0}$. If the foreign tariff is now removed, the firm's demand curve rotates to $d_{1}$ and the firm is

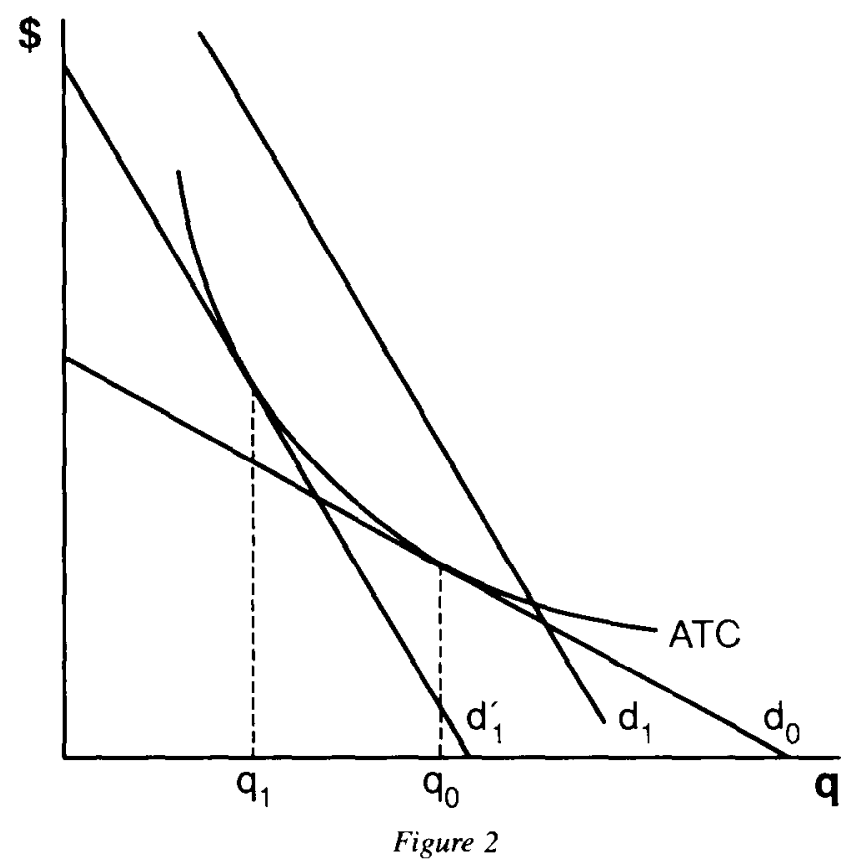


temporarily earning positive profits. Entry now occurs until profits are once again zero. The firm's demand curve shifts from $d_{1}$ to $d_{1}{ }^{\prime}$ and firm output falls to $q_{1}$. The market access provided by the partner country's tariff reduction will thus not be an important source of rationalization gain in the monopolistically competitive market structure. Rather, liberalization tends to enhance the market power of exporting firms in a market. Exporting firms respond by raising price and reducing sales.

Alternatively, consider the impact of liberalization on import-competing home-country firms. The tariff reduction lowers the price of competing imports, which in turn raises the local firm's perceived elasticity of demand, as noted above. In other words, the fall in the tariff reduces the market power of domestic firms on their sales in the domestic market, leading firms to lower price and increase sales. This is frequently referred to as the procompetitive effect of liberalization.

We conclude then that each country's own tariff reductions are a more important force in stimulating rationalization gains than are reductions in the partner tariff. This suggests therefore that, since Canada's tariffs are noticeably higher than U.S. tariffs, the procompetitive effect of rationalization is likely to be more pronounced for Canadian firms than for U.S. firms.

A change in world prices exercises a still further influence on the shape of the firm's demand curve. Removal of Canada's relatively high tariffs is expected to worsen Canada's terms of trade. The rise in the relative price of U.S. produced goods on the Canadian market is associated with a fall in the perceived elasticity of demand of Canadian firms, offsetting some of the pro-competitive effect of liberalization. The opposite will be the case for the United States. The price of Canadian goods on the U.S. market will fall by more than the reduction in the U.S. import tariff due to the decline in the world price of Canadian goods. U.S. firms will respond by raising output.

Throughout the above discussion we have held the shape of the ATC curve fixed. Let us turn now to the effect of trade liberalization on the underlying cost structure, while holding the firm's perceived elasticity of demand constant. In the spirit of traditional trade theory, consider a simple two-sector model. Let industry 1 be perfectly competitive and industry 2 be monopolistically competitive with production requiring a fixed input of capital plus variable inputs of capital and labor.

Suppose first, that sector 2 is labor intensive relative to sector 1 . We expect that a tariff reduction in sector 2 would cause production in the import competing sector to decline, releasing factors to the export sector. Since sector 2 is taken to be labor intensive, the wage-rent ratio must fall to clear the factor markets. Now, since labor's share of variable cost is greater than labor's share of total cost in industry 2, it follows that MC will fall relative to ATC as a result of the change in factor prices. To preserve the profitmaximizing price-cost margin, A'C must fall further. This is accomplished by raising firm output, thereby raising ATC.

Alternatively, suppose that sector 2 is relatively capital intensive. Now, as factors exit the import competing industry, the wage-rent ratio must rise. As a result, $\mathrm{MC}$ now rises relative to ATC so that the price-cost gap is narrowed. In order to raise ATC independently of MC, firm output must fall.

We see, then, that technology and market structure can interact in surprising ways that dramatically alter the rationalization effects of a tariff reduction. The ultimate implications of trade liberalization for the realization of scale economies will depend on the potentially competing influences of the elasticity of demand and factor prices on firm output.

If we extend the horizons of our model to include a second country, our intuitive 
understanding is further strained. Consider a hypothetical situation in which two identical countries are engaged in tariff-free trade. In the event that the home-country imposes a tariff on the foreign country, our intuition suggests that home country firms perceive a less elastic demand curve and respond by raising price and reducing output. Firms in the foreign country do the opposite, raising output and lowering price.

Now, if supply of a representative home firm is to fall relative to foreign firm supply, then total demand for a home firm (domestic plus exports) must also fall relative to total foreign-firm demand. In order for this to be so, we must place some restrictions on the change in relative prices that can occur.

On the one hand, we expect that the tariff will raise domestic demand for a typical home firm relative to a foreign firm among domestic consumers. On the other hand, we expect changes in the terms of trade to lower demand for home firms relative to the foreign firms among foreign consumers. If, on balance, total home firm demand is to fall relative to foreign firm demand, then the latter price change must dominate. This implies that the terms of trade for the home country must improve enough that, averaging over consumers in both countries, the consumer price of the home good rises relative to the consumer price of the foreign good. Mathematically, we have

$$
\hat{P}_{H}>\hat{P}_{F}+g_{M} \hat{t}
$$

where $g_{M}$ is the import budget share in the home country, $t$ is the tariff imposed, $P_{i}$ is the world price of a representative firm in country $i$, and the circumflex indicates proportionate change.

However, the condition given by Equation (1) is precisely that under which the perceived elasticity of demand for home firms rises relative to foreign firms. It is true that the tariff raises the landed price of imports in the home country, which lowers the perceived elasticity of demand for the home firm relative to the foreign firm. However, the requisite change in the terms of trade causes the home price to rise relative to the foreign firm price in the foreign market, which raises the perceived elasticity of demand for the home firm relative to the foreign firm. Equation (1) says that the latter dominates, and the perceived elasticity of demand for the home firm rises relative to the foreign firm.

The problem here is that, in the context of the utility functions usually adopted in analyzing the Canada-U.S. FTA, it is difficult to have quantity sold and elasticity of demand both rising for a representative home firm relative to a foreign firm and still be on the firm's demand curve. The proper intuition is that, if firm output is rising, then the firm must be moving down its demand curve to points where demand is less elastic, as compared to a foreign firm.

We conclude then that the link between trade liberalization and the realization of scale economies is less intuitive in the monopolistically competitive market structure than under focal pricing. The inter-linkage among the factor intensity ranking of industries, changes in the terms of trade, and the initial tariff levels will ultimately govern the level of firm output. It is difficult to anticipate the ultimate outcome for Canada.

\section{Tariff Liberalization and the Terms of Trade}

We have noted above that Canada's pre-FTA tariffs are high relative to U.S. tariffs. For this reason, we expect bilateral liberalization to turn the terms of trade against Canada, resulting in a loss in welfare. However, in the monopolistically competitive setting, this 
need not be the case. It is true that the impact of liberalization will generate an excess supply of Canadian produced goods. But as will be shown below, the relative price changes necessary to restore equilibrium depend on the underlying technology and could involve a terms-of-trade gain for Canada.

We are interested in the general equilibrium relationship between price and output of a monopolistically competitive firm. Return again to the situation in which firms in the monopolistically competitive sector require a fixed input of capital plus variable inputs of capital and labor. Consider the case in which the monopolistically competitive sector (sector 2) is labor intensive when ranked according to its variable inputs.

The free-entry condition requires that price and ATC move proportionately and the profit-maximization condition requires that price and $\mathrm{MC}$ move proportionately as long as perceived elasticity of demand is held constant. Now, if the price of good 2 rises then the underlying factor prices must adjust in such a way as to raise $\mathrm{MC}$ in sector 2 without altering MC (and ATC) in sector 1. This is accomplished by raising the wage/rent ratio since sector 2 is labor intensive in its variable inputs. However, as before, labor's share of MC is greater than labor's share of ATC. Thus, a rise in the wage/rent ratio that raises MC in proportion to price must leave a representative firm in sector 2 earning positive profits. In order to restore the zero-profits condition, firm output must fall so that ATC can also rise in proportion to price.

Consequently, in this case, the general equilibrium relationship between price and firm supply is negative. Therefore, it is entirely possible that the excess supply of Canadian goods generated by trade liberalization will be removed by a higher price for Canadian goods relative to U.S. goods and, therefore, an improvement in Canada's terms of trade. We would normally rule out such a potentially unstable situation in a perfectly competitive model, but it is inappropriate to do so in this case because of the plausible nature of the underlying technology generating the result. Furthermore, the conditions for dynamic stability of an imperfectly competitive market structure are less restrictive than under perfect competition, so that problems with stability may not arise.

\section{Canada-U.S. FTA and Monopolistic Competition: What Can We Conclude?}

The foregoing discussion leaves us somewhat uncertain as to what we can expect from a model with monopolistically competitive firms. It is clear that the underlying technology will interact with each country's relative factor endowments to determine the impact of liberalization on economies of scale, terms of trade, and inter-sectoral factor movements. In particular, the capital-labor composition of fixed vs. variable costs is critical to the outcome.

Wigle's results noted earlier suggest that gains for Canada from liberalization will not be forthcoming if firms are predominantly monopolistically competitive. However, it is possible that the choice to retain NPD in addition to firm product differentiation lies behind Wigle's negative welfare result for Canada.

In this connection, Brown and Stern $(1989 \mathrm{a}, \mathrm{b})$ have constructed a multi-country computational model that is distinguished by the absence of both the NPD assumption and focal pricing behavior. Each firm produces a differentiated product but products are not differentiated by national origin. Most industries are monopolistically competitive and technology is increasing returns to scale. ${ }^{3}$ Firm production functions require a fixed input of capital and variable inputs of capital and labor, as in the above discussion.

This model has been used to evaluate post-Tokyo Round (1987) bilateral tariff removal. 
As noted in Table 1, Canada's welfare rises by an estimated 1.1 percent and U.S. welfare rises by 0.1 percent. The realization of economies of scale is playing a role in raising Canada's welfare as firm output rises in 16 of the 24 imperfectly competitive sectors. There is also a strong pattern of inter-sectoral specialization. Canadian resources flow particularly toward five of the 22 tradable sectors and the United States specializes in twelve sectors. Finally, Canada's terms of trade deteriorate by 0.2 percent, which is very small compared to the the 2.6 percent decline reported by Wigle.

We conclude from this discussion that the FTA is very likely to be welfare improving for Canada. Once we succeeded in constructing CGE models that allow the traditional sources of gains from liberalization to emerge, the FTA was shown to be advantageous for both nations. Plausible estimates of Canada's welfare gain range from one percent to 2.5 percent of GNP. The gain will be on the higher end of this range if tariff protection has fostered Eastman-Stykolt type collusive firm behavior. In contrast, the impact on the United States is expected to be quite small, but the agreement should still raise U.S. welfare.

\section{ADJUSTMENT AND DYNAMIC EFFECTS}

In all of the studies described so far, the removal of bilateral tariffs is assumed to take place all at one time. However, in view of the fact that the elimination of tariffs and selected NTBs is to be phased in over a period of ten years, it is interesting to consider the transition process in order to determine the economic effects involved and to identify and measure any costs of adjustment.

Harris and Kwakwa (1989) address transition effects of the FTA by using a sequenced (medium term) general equilibrium model that incorporates imperfect competition, scale economies, and certain labor market rigidities. They explore the dynamics of entry and exit of firms and the effects on employment and unemployment through time. The manufacturing firms follow a focal pricing strategy as in the Harris-Cox model, except that they do so in this model in order to determine their target price ex ante in the light of their anticipations of what the expenditure aggregates in the economy will be. Harris and Kwakwa make a special effort to model labor market turnover both within and between sectors in a labor market that is characterized by sluggish adjustment of nominal wages.

Compared to the earlier findings of Harris and Cox, when the sequencing of the bilateral tariff removal is taken into account, the economic impacts in a given year are bound to be small. Further, Harris and Kwakwa conclude that adjustment costs are comparatively small. The main reasons are that there are dynamic adjustment lags in firm behavior and in the labor market that serve to dampen effects that otherwise might be greater as well as positive employment and wage effects as firms adjust their investment in real capital in response especially to increased expenditure. Rationalization effects occur, but they are considerably smaller than in the Harris-Cox model. In effect, this model of the transition in the FTA gives a much more benign view of the adjustment process than earlier work based on a one-time assumed elimination of tariffs, and it suggests strongly that labor in Canada has much to gain from the FTA.

Little work has been undertaken to date to evaluate the dynamic effects of the FTA on saving, investment, and the trade balance. However, some insights on this issue can be found in Eichengreen and Goulder (1991) who bring together the Heckscher-Ohlin model 
of international trade and the intertemporal optimization model to study the time path of some macroeconomic variables in response to trade policy.

We can determine the effect of tariff elimination on the current account by analyzing the capital account. First, consider the effect of liberalization on saving. Trade liberalization will tend to worsen the terms of trade of the liberalizing country, thereby lowering permanent income. The volume of saving falls in turn. The opposite occurs in the partner country: terms of trade improve, permanent income rises, and the volume of saving rises.

Turning next to investment, there are two sources of capital misallocation that drive investment. First, the country that has relatively capital-intensive imports must ultimately lose capital. That is, tariff removal may widen the difference in relative factor abundance between the two countries.

Second, there is also inter-sector capital misallocation. Both countries must reallocate capital from their respective import-competing sector to the export sector. Capital leaves the import-competing sector through depreciation and enters the export sector through investment. Firms in the expanding sector find it profitable to raise their capital stock at a rate that exceeds the rate of capital depreciation. Consequently, the total capital stock in each country rises in the initial transition to the long run.

We thus have a situation in which both countries require considerable new investment but domestic saving has declined relative to foreign country saving. The end result is that foreign saving partially finances inter-sectoral capital reallocation in the liberalizing country. This is the case even if the liberalizing country eventually becomes a capital exporter.

The fundamental lesson here is that due to the process by which capital moves from one sector to another, the rate of depreciation in the contracting sector can easily (and is, indeed, likely to) be slower than the investment in the expanding sector. Consequently, the capital stock rises in both countries during the medium run, even though in the long run the liberalizing economy may lose capital.

The Eichengreen-Goulder results can provide us with a sensible reinterpretation of recent events surrounding the implementation of the Canada-U.S. FTA. During the negotiation there was considerable concern in Canada that U.S. firms would repatriate capital that had previously been installed in Canada for the purpose of jumping Canada's tariff wall. However, shortly after the 1987 Parliamentary elections that ensured approval of the agreement in Canada, Canada began experiencing a considerable capital inflow and an appreciating Canadian dollar. Then, around the middle of 1989 , we increasingly heard stories of plant closings as production moved south of the border. The Canadian dollar subsequently began to slide and a recession ensued.

We can understand the initial capital inflow and currency appreciation as part of the inter-sector reallocation that is expected to be considerable in Canada (but not in the United States). However, the initial capital inflow does not give us any information concerning the long run equilibrium Canada-U.S. capital allocation. Indeed, it appears likely that we will observe considerable repatriation of U.S. capital in the long run, despite the initial investment surge in Canada.

\section{MACROECONOMIC EFFECTS}

The bilateral elimination of tariffs and NTBs will lead to reductions in consumer prices, which may in turn result in an increase in the real disposable income of consumers. If this leads to increased consumer spending, the economies are operating at less than full 
employment, and domestic macroeconomic policies remain unchanged, then there will be an increase in real GNP, output, trade, and employment in the short-to-medium run. To the extent that these macroeconomic changes occur, they will reinforce the microeconomic benefits stemming from lower consumer prices, improvements in resource allocation, and industry rationalization.

It is evident in Table 1 that there have been several estimates of the effects of the FTA based on the use of macroeconometric models. The procedure essentially is first to use the macroeconometric model to determine the amount by which the import and export prices and volume of trade of the two countries may change. These factors are then entered as exogenous changes in the microeconomic framework and a solution obtained for changes in the variables of interest. There is a difficulty, however, in using macroeconometric models for this purpose since these models generally lack adequate closure properties and do not have well articulated microeconomic structures. It cannot be readily determined therefore how the aggregate results correspond to the results based on the general equilibrium models.

To illustrate this point, we may note, for example, that the Economic Council of Canada (Magun et al., 1987, 1988) used the CANDIDE econometric model of the Canadian economy to carry out two simulations of the effects of the FTA. The first simulation considered only the macroeconomic impacts of the bilateral removal of tariffs and certain NTBs while the second simulation involved an adjustment to take into account the possible rationalization (scale) effects that might occur in Canada. This necessitated decomposing the aggregate effects by sector on the basis of a Canadian input-output table and applying assumed rationalization coefficients for individual industries. The results thus reflect the structure of the CANDIDE macroeconometric model in combination with the input-output structure and scale economy parameters, but without explicit behavioral relations linking the various factors.

While the aforementioned studies have focused on the aggregate income and employment effects of the FTA, it is also important to consider how the FTA may affect the exchange rate and the incentives for international financial capital flows. Movement of the exchange rate will depend on how the FTA will affect the balance of trade and foreign direct investment. The exchange rate movement will also be influenced by the conduct of monetary and fiscal policies, which will be guided by macroeconomic objectives concerning aggregate employment, price stability, and economic growth. Since the exchange rate will thus be affected by a variety of economic forces and policies during any given period of time, this means that it could be difficult to determine how the FTA in itself will affect the exchange rate. Further, in analyzing the economic effects of the FTA, it will be necessary to determine the extent to which changes in the exchange rate will reinforce or offset the effects of bilateral liberalization resulting from the FTA.

\section{UNRESOLVED ISSUES}

There are several unresolved issues in analyzing the FTA that deserve more careful attention. These issues include: intra-firm trade; foreign direct investment; modeling of NTBs; the reduction in the uncertainty of policies; and the dynamic gains from the formation of human and physical capital. Lying at the center of most of these issues is our 
inadequate understanding of imperfectly competitive market structures and firm behavior in the context of preferential trading arrangements.

\section{Intra-Firm Trade}

Much of the existing cross-border trade consists of intra-firm trade in intermediate inputs. It would appear that the realization of scale economies in the production of intermediate inputs due to tariff liberalization will depend on the transfer-pricing behavior of firms. If there are active markets in intermediate inputs, a profit-maximizing firm may value its intermediate inputs at their next best alternative. In this case, intermediate input trade can be modeled in the same manner as final goods trade. Changes in tariffs and the terms of trade will alter firm behavior consistent with whichever model is thought best to capture the market structure. However, if intermediate inputs are manufactured within the firm and markets for these inputs do not exist, firms may value intermediate input trade at marginal cost. As a result, we may observe declining ATC but marginal cost transfer pricing. The realization of scale economies in intermediate inputs turns then on the effect that tariffs on final output have on firm perceived elasticity of demand and the effect that tariffs on intermediate inputs have on the marginal cost of production. Thus, models that do not distinguish trade in intermediate inputs from trade in final goods would be deficient in this situation.

\section{Foreign Direct Investment}

Closely related to the issue of intra-firm trade is the question of the effect of the FTA on foreign direct investment (FDI). While we have assumed thus far that factors are immobile between countries, there are likely, in fact, to be changes in FDI as a result of the FTA. Early discussions of the FTA focused on the possibility that U.S. owned capital installed in Canada might be repatriated as a result of tariff removal. Under the assumption that products are homogeneous and markets are perfectly competitive, such repatriation is welfare improving for Canada. This is the case since FDl causes capital to be paid its internal marginal value product (MVP), which exceeds its marginal product valued at world prices by the amount of the tariff. This result does not hold, however, when products are differentiated either by firm or country. In the monopolistic competition case, import tariffs do not alter the equality between the price of the domestically produced good on the domestic market and its price on the world market. As a result, imported capital is paid its true MVP, even in the presence of a tariff.

Since the advent of the FTA, it has been suggested that capital is being attracted to Canada from third countries such as Japan in order to take advantage of Canada's access to the U.S. market. But this argument is not clear since it does not explain why this capital is not installed in the United States directly.

We have limited information from the CGE models concerning the likelihood and direction of FDI, although the reasons for the capital flow are not obvious. Harris (1984) models the supply of capital to Canada as perfectly elastically supplied at the world interest rate. His results suggest that considerable capital will be attracted to Canada. In contrast, results obtained in Brown (1990) and Brown and Stern (1989a,b) are mixed. While they do not model capital as mobile internationally, presumably capital will be attracted to countries that experience an increase in the rate of return. Some results on the return to capital under various assumptions are reported in Table 2.

It is evident in Table 2 that the return to capital in the United States generally falls. 
TABLE 2. Percent Change in the Return to Capital Canada-U.S. Bilateral Tariff Removal

\begin{tabular}{lcr} 
& \multicolumn{2}{c}{ Return to Capital (Percent Change) } \\
\cline { 2 - 3 } Market Structure & United States & \multicolumn{1}{c}{ Canada } \\
\hline Brown (1990) & & \\
PC \& MC (sigma = 3) & -0.04 & 0.26 \\
PC \& MC (sigma = 15) & 0.05 & -1.10 \\
PC \& OLG (sigma = 3) & -0.03 & 0.08 \\
PC \& OLG (sigma = 15) & -0.09 & -0.02 \\
PC \& MS (No Entry) & -0.04 & 0.26 \\
PC \& MS (Entry) & -0.27 & 4.30 \\
Hybrid & -0.10 & 0.20 \\
& & \\
Brown and Stern (1989a) & & 0.40 \\
PC (sigma = 15) & -0.10 & -1.10 \\
MC (sigma = 15) & 0.10 & 1.30 \\
MS (Entry) & 0.10 & -0.10 \\
Brown and Stern (1989b) & -0.10 & \\
\hline
\end{tabular}

PC-Perfect competition with national production differentiation

MC-Monopolistic competition with firm product differentiation.

OLG-Oligopoly with differentiated products and no entry.

MS-Market Scgmentation with homogeneous products across firms but no arbitrage between national markets. See Venables (1985).

sigma-elasticity of substitution among different varieties of a good in the utility and production functions.

Hybrid-Each sector assigned one of the above market structures.

Therefore, it does not seem likely that capital will be attracted into the United States, either from third countries or from Canada. The results for Canada are mixed and depend on the market structure and parameter values assumed. For example, under the assumption that markets are segmented but there is free entry, the return to capital in Canada rises by 4.3 percent, whereas the rental rate falls by 1.1 percent if markets are monopolistically competitive but a high degree of product substitutability is assumed. It is not clear why this discrepancy occurs, so further work on this question is needed.

\section{Nontariff Barriers}

There are existing bilateral NTBs that affect Canada-U.S. trade, but only some of them are to be removed as the result of the FTA. It is common in analyzing NTBs to do so in terms of their tariff equivalents. While this is convenient, it can be quite misleading if the markets involved are not perfectly competitive. It would be useful accordingly to review those NTBs that are scheduled for reduction or removal in light of the market structure and behavior of the firms that will be affected in an effort to determine what the outcome may be. By the same token, a similar review of the relation between NTBs and market structure would be revealing for those NTBs that are to remain intact but possibly be subject to bilateral negotiation for their removal at some future time.

\section{Reduction in the Uncertainty of Policies}

While our discussion has focused on the bilateral removal of trade barriers, the FTA may be quite beneficial due to the changes to be made in the rules and procedures governing international trade and investment relations between Canada and the United 
States. These include the agreements that limit the use by Canada of investment performance requirements for foreign affiliates of U.S. firms, the guarantee of national treatment and rights of establishment for foreign firms investing in most industries, the removal of Canadian duty remission schemes that had been condoned in the U.S.-Canadian Auto Pact, and less nationalistic and potentially discriminatory Canadian energy policies.

New bilateral dispute settlement procedures have been established that could be especially important to Canada. These procedures are designed to depoliticize the investigation of trade and investment disputes and to reduce the likelihood that politically driven and therefore damaging actions will be taken by the United States. The costs of conducting trade and investment transactions may thus be materially reduced as the result of the FTA, and are thus deserving of careful investigation.

\section{Dynamic Gains from Trade}

We noted earlier that the transition process in implementing the FTA involves a number of important dynamic aspects of the behavior of firms and the associated impacts on wages and employment. But it is conceivable that the FTA might have dynamic effects in its own right. These effects may work through changes in the business environment that may be conducive to economic expansion and to the adoption of technological improvements. It is also possible, as Baldwin $(1989 \mathrm{a}, \mathrm{b})$ has suggested in connection with the European Community's 1992 program of further integration and liberalization, that the FTA could increase the accumulation of both physical and human capital. Depending upon the capital-labor ratio, output might therefore increase much more than otherwise.

\section{CONCLUSIONS AND IMPLICATIONS FOR FUTURE RESEARCH}

We have made an effort in this paper to identify a number of conceptual issues that are pertinent to analyzing the economic effects of the Canada-U.S. FTA. In an important sense, our treatment of these issues has reflected the ways in which the thinking about bilateral free trade between Canada and the United States has evolved in the past two decades or more. Canadian economists such as the Wonnacotts, Harris and Cox, and others have placed great emphasis on the ways in which Canada's trade policies have interacted with imperfectly competitive firms in the Canadian manufacturing sector and the potentially large benefits that might be realized from rationalization effects brought about by an FTA. At the same time, other economists investigating these matters have relied on more conventional modeling assumptions based on perfect competition and constant returns to scale.

Our own approach to analyzing the FTA has evolved in ways that try to synthesize the important elements of both approaches and to embed these elements in a comprehensive general equilibrium modeling framework. At the same time, we are acutely aware that there are several issues that neither we nor others have yet treated theoretically or computationally that may in fact be quite important. So there is more work to be donc.

In our introduction, we noted that the computational studies of the FTA have produced a wide array of results so that exactly how the FTA may affect such important matters as economic welfare, labor market adjustments, the realization of scale economies, foreign direct investment, and the productivity gap between Canada and the United States remains 
unclear. Now that the FTA is a reality, the challenge is to develop a more explicit econometric methodology that incorporates the many modeling features and issues that we have sought to identify in our discussion and to focus more directly on how the FTA has operated in fact rather than hypothetically.

Acknowledgments: This is a revised version of a paper originally presented at a joint seesion of the Annual Meetings of the American Economic Association and the North American Economics and Finance Association, Atlanta, GA, December 28, 1989. Helpful comments were received from C. Michael Aho, Sven W. Arndt, Tim Hazeldine, Randy Wigle, Ronald J. Wonnacott, and anonymous referees. Financial assistance was provided in part by a grant from the Ford Foundation for a program of research in trade policy in the Institute of Public Policy Studies at the University of Michigan. We are grateful to Judith Jackson for editorial assistance and typing.

\section{NOTES}

1. See Hazledine $(1988,1990)$ for a discussion and computational illustrations that parallel some of the issues that we will address.

2. An interesting question here is that empirical estimates of country-specific export demand elasticities often appear to be relatively small, which would appear to support the Armington assumption. In our view, it may well be the case that the relevant elasticities are fairly small in the short run, but these elasticities should be substantially greater in the long run. Moreover, when we change the focus of the analysis to permit product differentiation by firms, it is likely that there would be relatively large demand elasticities for product varieties that are close substitutes among firms in a given sector.

3. Several industries are classified either as perfectly competitive or as various forms of oligopoly.

\section{REFERENCES}

Baldwin, Richard E. 1992. "Measurable Dynamic Gains from Trade," Journal of Political Economy, 100(1): 162-174.

Baldwin, Richard E. 1989b. "On the Growth Effects of 1992." Economic Policy, Fall.

Boadway, Robin, and John Treddenick. 1978. "A General Equilibrium Computation of the Effects of the Canadian Tariff Structure." Canadian Journal of Economics, 11: 424-446.

Brown, Drusilla K. 1987. "Tariffs, the Terms of Trade, and National Product Differentiation." Journal of Policy Modeling, 9(3): 503-526.

Brown, Drusilla K. 1991. "Tariffs and Capacity Utilization by Monopolistically Competitive Firms." Journal of International Economics, 30(3/4): 371-381.

Brown, Drusilla K. 1990. "General Equilibrium Analysis of Tariff Removal Under the U.S.-Canada Free Trade Agreement: Market Structure and Firm Pricing Behavior." Bureau of International Labor Affairs, U.S. Department of Labor, Washington, DC.

Brown, Drusilla K., and Robert M. Stern. 1987. "A Modeling Perspective." In Robert M. Stern, Philip H. Tresize, and John Whalley (eds.), Perspectives on a U.S.-Canadian Free Trade Agreement. Washington, DC: The Brookings Institution.

Brown, Drusilla K., and Robert M. Stern. 1989a. "Computable General Equilibrium Estimates of the Gains from U.S.Canadian Trade Liberalisation." In David Greenaway, Thomas Hyclak, and Robert J. Thornton (eds.), Economic Aspects of Regional Trading Arrangements. London: Harvester Wheatsheaf. 
Brown, Drusilla K., and Robert M. Stern. 1989b. "U.S.-Canada Bilateral Tariff Elimination: The Role of Product Differentiation and Market Structure." In Robert C. Feenstra (ed.), Trade Policies for International Competitiveness. Chicago: University of Chicago Press.

Dungan, Peter. 1985. "The Macroeconomic Impacts of Free Trade with the United States: Lessons from the FOCUS-PRISM Models." Institute for Policy Analysis, University of Toronto, Working Paper, DP 85-86 (November).

Eastman, H. C., and S. Stykolt. 1967. The Tariff and Competition in Canada. Toronto: University of Toronto Press

Eichengreen, Barry, and Lawrence H. Goulder. 1991. "The Impact of Permanent and Temporary Import Surcharges on the U.S. Trade Deficit." In Robert E. Baldwin (ed.), Empirical Studies of Commercial Policy. Chicago: University of Chicago Press.

Government of Canada, Department of Finance. 1988. The Canada-U.S. Free Trade Agreement: An Economic Assessment. Ottawa.

Hamilton, Bob, and John Whalley. 1985. "Geographically Discriminatory Trade Arrangements." Review of Economics and Statistics, LXVII: 446-455.

Harris, Richard. 1984. "Applied General Equilibrium Analysis of Small Open Economies with Scale Economies and Imperfect Competition." American Economic Review, 74: 1016-1032.

Harris, Richard G., with David Cox. 1984. Trade, Industrial Policy, and Canadian Manufacturing. Toronto: Ontario Economic Council.

Harris, Richard G., and David Cox. 1985. "Summary of a Project on the General Equilibrium Evaluation of Canadian Trade Policy." In John Whalley (ed.), Canada-United States Free Trade, Vol. 11. Research Studies, Royal Commission on the Economic Union and Development Prospects for Canada. Toronto: University of Toronto Press.

Harris, Richard G., and Victoria Kwakwa. 1989. "The 1988 Canada-United States Free Trade Agreement: A Dynamic General Equilibrium Evaluation of the Transition Effects." Queen's University, Discussion Paper No. 744 (May).

Hazledine, Tim. 1988. "Canada-U.S. Free Trade? Not So Elementary, Watson." Canadian Public Policy, 14: 204-210.

Hazledine, Tim. 1990. "Why Do the Free Trade Gain Numbers Differ So Much? The Role of Industrial Organization in General Equilibrium." Canadian Journal of Economics, 23: 791-806.

Informetrica Ltd. 1985. "Economic Impacts of Enhanced Bilateral Trade: National and Provincial Results." Prepared for the Department of External Affairs, Government of Canada.

Magun, Sunder, Someshwar Rao, and Bimal Lodh. 1987. "Impact of Canada-U.S. Free Trade on the Canadian Economy." Economic Council of Canada, Discussion Paper No. 331 (August).

Magun, Sunder, Someshwar Rao, and Bimal Lodh, Laval Lavallee, and Jonathan Pierce. 1988. "Open Borders: An Assessment of the Canada-U.S. Free Trade Agreement." Economic Council of Canada, Discussion Paper No. 344 (April).

Markusen, James, and Randall M. Wigle. 1986. "U.S.-Canada Free Trade: Effects on Welfare and Sectoral Output/Employment Levels in the Short and Long Run." Bureau of International Labor Affairs, U.S. Department of Labor, Washington, DC.

Trela, Irenc, and John Whalley. 1990. "Unravelling the Threads of the MFA," In Carl B. Hamilton (ed.), Textiles Trade and the Developing Countries: Eliminating the Multi-Fibre Arrangement in the 1990s. Washington, DC: The World Bank.

Venables, Anthony J. 1985. "Trade and Trade Policy with Imperfect Competition: The Case of Identical Products and Free Entry." Journal of International Economics, 19: 1-20.

Wharton Econometrics. 1987. "Canada-U.S. Free Trade: Opportunities, Risks and Prospects," September.

Wigle, Randall M. 1988. "General Equilibrium Evaluation of Canada-U.S. Trade Liberalization in a Global Context." Canadian Economic Journal, XXI: 539-564.

Wonnacott, Ronald J., and Paul Wonnacott. 1967. Free Trade Between the United States and Canada. Cambridge: Harvard University Press. 